\title{
EKSTRAKSI ANDROGRAFOLID DARI Andrographis paniculata (Burm.f.) Nees MENGGUNAKAN EKSTRAKTOR SOXHLET
}

\section{ANDROGRAPHOLIDE EXTRACTION FROM Andrographis paniculata (Burm.f.) Nees USING SOXHLET EXTRACTOR}

\author{
Ichwan Ridwan Rais \\ Fakultas Farmasi Universitas Ahmad Dahlan \\ Jl. Prof. Dr. Soepomo SH, Yogyakarta, Telp. (0274) 379418 \\ Email: ichwanridwanrais@yahoo.co.id
}

\begin{abstract}
ABSTRAK
Proses ekstraksi senyawa kimia yang terkandung dalam tanaman dapat dipengaruhi berbagai aspek, baik dari teknis penyarian maupun faktor tanaman itu sendiri. Sistem penyarian dan polaritas pelarut sangat menentukan perpindahan senyawa kimia tanaman dari dalam sel ke dalam cairan pelarut. Alat soxhlet adalah suatu sistem penyarian berulang dengan pelarut yang sama yang menggunakan proses sirkulasi perubahan uap - cair dari pelarut dengan pemanasan. Polaritas cairan pelarut yang digunakan bergantung dari sifat kimia senyawa aktif yang akan diekstraksi dan kemampuan menembus membran sel. Andrografolid merupakan senyawa kimia aktif yang telah terbukti memiliki aktivitas pengobatan dan dapat dijadikan senyawa penentu aktivitas dari herba Andrographis paniculata. Andrografolid memiliki sifat keterlarutan dalam pelarut semi polar yang menandakan pemilihan jenis pelarut yang cocok dalam mengekstraksi. Penelitian ini menunjukkan bahwa proses penyarian komponen kimia yang terkandung di dalam tanaman dipengaruhi polaritas pelarut yang digunakan. Hasil analisis kualitatif KLT menggunakan pelarut sangat polar ataupun sangat non polar tidak mampu menarik senyawa kimia aktif andrografolid dari simplisia dengan noda yang tidak terlihat pada $\mathrm{UV}_{254}$, berbeda dengan pelarut semi polar. Proses ini juga memberikan informasi pengaruh kemampuan pelarut dalam penetrasi melewati mekanisme pertahanan membran sel tanaman. Penggunaan pelarut dengan polaritas yang cocok dan sistem penyarian yangsesuai dalam mengekstraksi andrografolid dari Andrographis paniculata memberikan hasil ekstraksi yang memenuhi persyaratan yang ditetapkan (16,6\%).
\end{abstract}

Kata kunci: Andrografolid, Soxhlet, polaritas.

\begin{abstract}
Chemical component extraction from plant herbal influenced by various aspect, such as extraction technique or chemical component character from the plant. Extraction method and solvent polarity exteremly influence chemical component transfer from the cell of plant to solvent solution. Soxhlet is extraction system instrument with frequently same solvent extraction based on liquid-steam circulation process of the solvent. Solvent polarity to extract chemical component of the plant herbal depend on chemical component character it self and ability to penetrate cell membrane. Andrographolide, an active chemical component of Andrographis paniculata has been suggested the most active constituent that responsible to activity of Andrographis paniculata in herbal medication. This chemical constituen has solubility character in solvent with middle polarity that indicates solvent election to extract it. This study shows that chemical component extraction of herbal plant influenced by solvent polarity. Thin Layer Chromatography qualitative analyses indicate that absolute polar and
\end{abstract}


nonpolar solvent could not extract andrographolide, different from middle polarity. Andrographolide extraction with similar solvent and correct method offer extract yield with 16,6\% andrographolide.

Key words : Andrgrapholide, soxhlet, polarity

\section{PENDAHULUAN}

Sambiloto (Andrographis paniculata (Burm.f.) Ness.) adalah salah satu tanaman Indonesia yang banyak digunakan secara tradisional dimasyarakat sebagai obat penyakit diabetes mellitus (Sudarsono et.al., 2006). Tanaman ini mengandung diterpen lakton yang terdiri dari andrografolid (zat pahit), neoandrografolid, 14-deoksiandrografolid, 14deoksi-11-oksoandrografolid (Niranjan et.al., 2010; Sudarsono et.al., 2006; Chao dan Lin, 2010). Andrografolid paling aktif dibandingkan yang lainnya (Soediro, 1973). Kandungan senyawa aktif yang berkhasiat dan berasal dari bahan alam memiliki karakteristik tertentu dalam kelarutan. Penelitian tentang metode ekstraksi dan cairan penyari yang terbaik dalam mengambil senyawa aktif dari simplisia dapat membantu proses isolasi senyawa aktif andrografolid.

Ekstraksi menggunakan Soxhlet dengan pelarut cair merupakan salah satu metode yang paling baik digunakan dalam memisahkan senyawa bioaktif dari alam. Cara ini memiliki beberapa kelebihan dibanding yang lain antara lain sampel kontak dengan pelarut yang murni secara berulang, kemampuan mengekstraksi sampel lebih tanpa tergantung jumlah pelarut yang banyak. Karena bagaimanapun, dengan alasan toksisitas, prosedur obat dan pengobatan harus menekan penggunaan pelarut dalam proses farmasetis. Penggunaan pelarut juga dapat mempengaruhi kinetika kristalisasi dan morfologi kristal dari produk (Kolar et al. 2002 cit. Kumoro, 2004).

Metode serta pelarut yang digunakan untuk memperoleh ekstrak menjadi faktor penting dalam optimasi proses ekstraksi komponen bioaktif dari alam. Tujuan penelitian ini untuk mendapatkan pelarut yang mampu mengekstraksi andrografolid paling tinggi konsentrasinya dalam ekstrak.

\section{METODE PENELITIAN}

\section{Alat}

Alat yang digunakan untuk penyarian adalah seperangkat alat penyari, tangas air, KLT dengan fase diam silika gel $60 \mathrm{~F}_{254}$, lampu UV, HPTLC (Camag) dan alat-alat gelas yang lazim digunakan.

\section{Bahan}

Sambiloto yang digunakan adalah herbanya yang diperoleh pada bulan juli dari Desa Girimulyo, Kecamatan Nanggulan, Kabupaten Kulon progo. Identifikasi tanaman dilakukan di Laboratorium Farmakognosi, Bagian Biologi Farmasi, Fakultas Farmasi, Universitas Gadjah Mada. Pelarut heksan, kloroform, etanol dan metanol dengan derajad pro analis dan teknis serta aquadestillata.

\section{Jalannya Penelitian}

\section{Penyiapan bahan}

Herba sambiloto yang digunakan dikeringan untuk mengurangi kadar air dalam tanaman agar reaksi enzimatik dapat dihentikan sehingga tidak mudah rusak. Pengeringan dilakukan dengan memasukkan herba kedalam oven dengan suhu $40^{\circ} \mathrm{C}$ untuk mendapatkan kadar air simplisia $<10 \%$. Herba sambiloto yang sudah kering dihaluskan dengan mesin blender hingga menjadi serbuk. Serbuk simplisia sambiloto kemudian diayak dengan ayakan 20 mesh.

\section{Pembuatan ekstrak herba sambiloto}

Serbuk herba sambiloto sebanyak 100 gram disari menggunakan alat soxhlet dengan cara membungkus serbuk herba dalam selongsong kertas saring dan dimasukkan ke dalam bagian rumah siput.Cairan penyari dengan polaritas yang berbeda ditambahkan sebanyak 
dua kali sirkulasi. Alat soxhlet kemudian diletakkan di atas pemanas dan dihubungkan dengan pendingin yang dialiri air pada bagian atas. Proses penyarian dengan alat soxhlet dilakukan hingga cairan penyari yang merendam selongsong berisi serbuk dalam sifon terlihat bening tidak berwarna. Hasil penyarian yang tertampung pada labu alas bulat di bagian bawah kemudian diuapkan dan dipekatkan. Pemekatan ekstrak dilakukan dengan memindah larutan hasil penyarian yang diperoleh ke cawan porselin di atas penangas air untuk mendapatkan ekstrak kental. Ekstrak kental ini kemudian di uji kualitatif dan kuantitatif kandungan andrografolidnya menggunakan HPTLC (Camag).

\section{Uji kualitatif andrografolid}

Pada uji kualitatif andrografolid dalam ekstrak kasar dengan KLT, sesuai dengan uji kualitatif yang telah dilakukan oleh DepKes RI (2009) dan Aulia (2008). Pengujian secara kualitatif dengan KLT dilakukan dengan menyiapkan larutan uji $10 \mathrm{mg} / \mathrm{ml}$ dalam etanol untuk tiap ekstrak dari masing-masing pelarut. Sedangkan pembanding androgafolid $0,1 \mathrm{mg} / \mathrm{ml}$ dalam etanol. Sebagai fase gerak adalah kloroform:methanol (9:1) (Depkes, 2009). Fase diam menggunakan plat KLT silika gel 60 F254. Volume penotolan larutan uji dan pembanding sebanyak $5 \mu \mathrm{L}$. Pengamatan noda pada $\mathrm{UV}_{254}$.

\section{Uji kuantitatif andrografolid}

Tujuan dari uji kuantitatif adalah memberikan data kadar kandungan kimia tertentu sebagai identitas.Menurut Saifudin et al. (2011), informasi data kadar kandungan senyawa aktif dapat berkaitan pada efek farmakologinya. Dalam hal ini penetapan kadar andrografolid dilakukan dengan metode densitometri. Tahap yang dilakukan adalah menimbang ekstrak $\pm 20,0$ mg kemudian dilarutkan dengan $2 \mathrm{ml}$ etanol sehingga diperoleh konsentrasi $10 \mathrm{mg} / \mathrm{mL}$. Buat variasi konsentrasi standar andrografolid yaitu 1 $\mathrm{mg} / \mathrm{mL} ; 0,5 \mathrm{mg} / \mathrm{mL} ; 0,25 \mathrm{mg} / \mathrm{mL} ; 0,125 \mathrm{mg} / \mathrm{mL}$. Tujuan dilakukannya variasi konsentrasi untuk andrografolid standar adalah untuk membuat kurva baku. Kemudian totolkan pada plat KLT silika gel 60 F254 dan lakukan elusi dengan fase gerak (kloroform:metanol = 9:1). Volume penotolan untuk larutan uji ekstrak dan andrografolid standar sebanyak $5 \mu \mathrm{L}$. Plat yang sudah dielusi dianalisis dengan KLT densitometer. Dihitung perolehan kembali andrografolid dalam ekstrak.

\section{HASIL DAN PEMBAHASAN}

Seratus gram serbuk herba sambiloto disari dengan soxhlet menggunakan empat macam pelarut yang berbeda polaritasnya yaitu heksan, kloroform, etanol dan air sampai kandungan aktif tersari semua. Sistem penyarian menggunakan alat soxhlet dengan cara cairan penyari diisikan kedalam labu, kemudian serbuk simplisia dimasukkan kedalam selongsong kertas saring dan diletakkan dalam bagian sifon.

Proses ini dimulai setelah cairan penyari dipanaskan hingga mendidih dan uap cairan penyari naik keatas melalui pipa samping, kemudian diembunkan kembali oleh pendingin tegak. Cairan penyari akan turun ke dalam sifon dan merendam selongsong kertas serta melarutkan kandungan aktif serbuk simplisia, hingga suatu saat cairan penyari dalam sifon akan penuh dan mengalir turun ke dalam labu. Begitu seterusnya sirkulasi penyarian ini dilakukan sampai kandungan aktif simplisia tersari semua yang ditandai oleh cairan penyari yang merendam simplisia dalam sifon menjadi bening dan tidak berwarna. Cara ini lebih menguntungkan karena uap panas tidak melalui serbuk simplisia (Nurani, et.al, 2012).

Pengujian secara kualitatif dengan KLT yang dilakukan dengan larutan uji $5 \mathrm{mg} / \mathrm{ml}$ dalam etanol untuk tiap ekstrak dari masing-masing pelarut dan pembanding androgafolid $1 \mathrm{mg} / \mathrm{ml}$ dalam etanol menggunakan fase gerak kloroform:methanol (9:1) (Depkes, 2009), fase diam menggunakan plat KLT silika gel 60 F254 serta volume penotolan larutan uji dan pembanding sebanyak $5 \mu \mathrm{L}$.

Terlihat pada Gambar 1, totolan paling kiri adalah baku pembanding andrografolid $1 \mathrm{mg} / \mathrm{ml}$ dalam etanol. Empat totolan ke arah kanan berurutan adalah sampel uji ekstrak heksan, kloroform, etanol dan air. Noda ungu pada nilai Rf 0,26 menunjukkan noda dari andrografolid. Secara organoleptik visual terlihat bahwa noda andrografolid ada pada baku pembanding, pada sampel uji ekstrak kloroform dan ekstrak etanol. 
Pada sampel uji ekstrak heksan dan air tidak terlihat adanya noda ungu andrografolid.

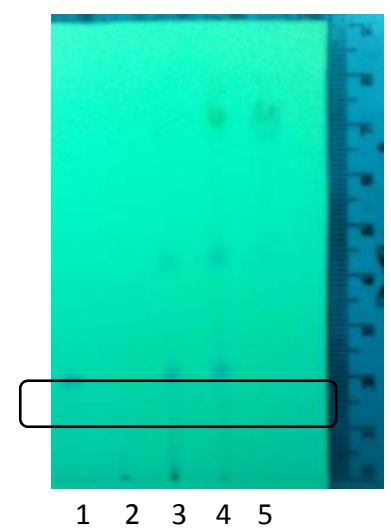

Gambar 1. Profil KLT5 uji kualitatif andrografolid (AG), elusi dilakukan dengan kloform:methanol (9:1), dengan fase diam silika gel 60 F254, pengamatan pada UV254 (1) AG standar; (2) ekstrak heksan; (3) ekstrak kloroform; (4) ekstrak etanol; (5) ekstrak air.

Pengamatan kualitatif pada UV254 ini kemudian dilanjutkan dengan pengujian kuantitatif untuk memastikan jumlah konsentrasi andrografolid yang ada pada masing-masing totolan.

Tabel I, menunjukkan data yang diperoleh berupa area densitometer dari KLT. Kurva baku standar andrografolid yang diukur adalah 4 macam konsentrasi yang selanjutnya akan dibuat persamaan regresi linier konsentrasi dibandingkan dengan luas area (LA).

Tabel I. Data konsentrasi andrografolid standar dan luas area (LA) puncak, C standar (mg/ml): konsentrasi andrografolid standar dalam mg/ml; LA standar: luas area andrografolid standar; LA/1000: luas area andrografolid standar dibagi 1000.

\begin{tabular}{|c|c|c|c|}
\hline $\begin{array}{l}\text { C } \\
\text { standar } \\
\text { (mg/ml) }\end{array}$ & $\begin{array}{l}\text { LA } \\
\text { standar }\end{array}$ & LA/1000 & $\begin{array}{l}\text { Persamaan } \\
\text { regresi }\end{array}$ \\
\hline 0,125 & 582,3 & 0,5823 & $\mathrm{Y}$ \\
\hline 0,25 & 2035,0 & 2,0350 & $10,233 X$ \\
\hline 0,5 & 3390,1 & 3,3901 & $-0,878$ \\
\hline 1 & 9668,6 & 9,6686 & $r=0,989$ \\
\hline
\end{tabular}

\section{HASIL DAN PEMBAHASAN}

Sampel ekstraksi sambiloto menggunakan pelarut heksan dan air tidak menunjukkan adanya noda andrografolid pada analisis kualitatif. Noda hanya terlihat pada pelarut ekstraksi dengan kloroform dan etanol. Heksan merupakan pelarut dengan indeks polaritas 0,1 (Luque et al. 1998 
cit. Kumoro, 2004) adalah paling rendah dan tidak dapat mengekstraksi senyawa aktif andrografolid dari herba sambiloto, sedangkan air merupakan pelarut dengan indeks polaritas tertinggi $(10,2)$ juga tidak dapat mengekstraksi senyawa aktif andrografolid dari herba sambiloto. Hal ini menunjukkan bahwa penggunaan pelarut dengan indeks polaritas yang sangat tidak polar atau sangat polar dalam mengekstraksi senyawa aktif andrografolid yang terkandung dalam bahan alam herba sambiloto tidak menghasilkan proses ekstraksi senyawa aktif target dengan baik.

Hasil analisis kualitatif pada KLT dengan pelarut kloroform yang memiliki indeks polaritas 4,1 (Luque et al. 1998 cit. Kumoro, 2004) dan pelarut etanol yang memiliki indeks polaritas 5,1 menunjukkan adanya noda senyawa andrografolid. Hal ini mengindikasikan bahwa penggunaan pelarut dengan indeks polaritas yang pertengahan atau semi polar dalam mengekstraksi senyawa aktif andrografolid yang terkandung dalam bahan alam herba sambiloto dapat menghasilkan proses ekstraksi senyawa aktif target dengan baik.

Hasil analisis kuantitatif dengan HPTLC menunjukkan data kandungan senyawa androfrafolid yang dapat diekstraksi dengan pelarut kloroform dan etanol menggunakan metode soxhletasi lebih dari $16 \%$. Hal ini membuktikan bahwa metode ekstraksi dengan cara tersebut dan menggunakan kedua pelarut tersebut dapat menghasilkan ekstrak dengan kadar yang memenuhi batas persyaratan yang ditetapkan Famakope Herbal Indonesia yaitu $15 \%$.

Herba bahan alam yang terdiri dari bagian tanaman seperti daun memiliki struktur sel yang terdiri dari lipoprotein yang memiliki struktur lemak non polar dan struktur protein yang memiliki sifat polar (Harborne, 1996). Struktur ini sulit dilalui oleh pelarut heksan yang sangat non polar dan pelarut air yang bersifat sangat polar sehingga kedua pelarut ini tidak dapat mengekstraksi senyawa aktif andrografolid dari dalam sel daun dengan baik. Pelarut dengan indeks polaritas pertengahan atau semi polar seperti kloroform dan etanol dapat menembus dinding sel daun dengan baik sehingga proses penyarian senyawa andrografolid dari dalam sel dengan kedua pelarut semi polar ini lebih direkomendasikan. Senyawa andrografolid merupakan diterpen lakton (Sudarsono et al. 2006) yang larut dalam pelarut semi polar seperti etanol, aseton dan kloroform dan sedikit larut dalam air. Meskipun sedikit larut dalam air, hasil analisis kualitatif ekstrak air tidak menunjukkan adanya noda andrografolid. Sehingga, faktor yang mempengaruhi penyarian senyawa target ekstraksi andrografolid dari herba sambiloto tidak hanya pada daya larut senyawa andrografolid ke dalam pelarut yang digunakan tetapi juga daya tembus pelarut tersebut melewati dinding sel bagian tanaman yang digunakan.

Ekstraksi menggunakan Soxhlet dengan pelarut cair merupakan metode yang paling baik digunakan dalam memisahkan senyawa bioaktif dari alam. Kelebihan cara ini dibanding yang lain adalah (Luque et al. 1998 cit. Kumoro, 2004):[i] sampel kontak dengan pelarut yang murni secara berulang sehingga membantu pemindahan keseimbangan konsentrasi kandungan komponen kimia dari simplisia ke dalam pelarut, [ii] suhu dalam system soxhlet relatif lebih tinggi dibanding panas yang diperlukan tabung destilasi, [iii] ekstraksi dapat ditingkatkan dengan penyarian paralel, [iv] kemampuan mengekstraksi sampel lebih tanpa tergantung jumlah pelarut.

\section{KESIMPULAN}

Senyawa andrografolid bersifat larut dalam pelarut semi polar seperti etanol dan kloroform. Proses ekstraksi andrografolid dari herba sambiloto tidak hanya dipengaruhi oleh keterlarutan senyawa andrografolid dalam pelarut yang digunakan tetapi juga oleh kemampuan pelarut tersebut menembus membran sel tanaman. Metode penyarian menggunakan alat soxhlet dengan pelarut kloroform dan etanol dapat digunakan untuk mengekstraksi senyawa andrografolid dari herba sambiloto dengan kadar yang memenuhi persyaratan yang ditetapkan

\section{SARAN}

Perlu dilakukan perbandingan langsung berbagai macam proses ekstraksi senyawa andrografolid dalam satu penelitian dan pengujian lebih lanjut tentang potensi senyawa andrografolid dalam aktivitas farmakologi. 


\section{UCAPAN TERIMAKASIH}

Penelitian ini dibiayai oleh Lembaga Penelitian dan Pengembangan Universitas Ahmad Dahlan tahun anggaran 2012.

\section{DAFTAR PUSTAKA}

Agarwal, R., Sulaiman, S.A., Mohamed, M. 2005. Open Label Clinical Trial to Study Adverse effect and Tolerance to Dry Powder of the Aeral Part of Andrographis paniculata in Patient Type 2 with DM, Malay. J.of Med. Sci. 12(1): 13-19.

Aulia, N. 2008. Penetapan Kadar Andrografolid dan Kurkumin dalam Ekstrak Campuran Herba Sambiloto dan Rimpang Kunyit dengan Metode KLT-densitometri, Universitas Airlangga, Skripsi, Surabaya.

Chao, W.W. and Lin, B.F. 2010. Isolation and Identification of Bioactive Compounds in Andrographis paniculata (Chuanxinlian), Chinese Medicine Journal. 5:1-15.

Chaves, J.S., DaCosta, F.B., de Frietas, L.A.F. 2009. Development of Enteric Coated Tablet From Spray Dried Extract of Fewerfew (Tanacetum parthenium L.), Braz. J. Phar.Sci. 45(3): 573-84.

Dandu, A.M., dan Inamdar, N.M. 2009. Evaluation of beneficial effectsof antioxidant properties of aqueous leaf extract of Andrographis paniculata in STZ-induced diabetes. J.Pharm Sci. 22(1):49-52.

Dep Kes RI. 2005. Pharmaceutical Care Untuk Penyakit Diabetes Mellitus, Dep Kes RI, Jakarta. PP:16, 24, 36-46.

Depkes RI. 1986. Sediaan Galenik, Departemen Kesehatan RI, Jakarta.

Depkes RI. 2009. Farmakope Herbal Indonesia, Departemen Kesehatan RI, Jakarta.

Kolar, P., Shen, J. W., Tsuboi, A \& Ishikawa, T. 2002. Solvent selection for pharmaceuticals, Fluid Phase Equilibria, 194 - 197, 771-782.
Harborne, J.B. 1996. Metode Fitokimia, Penuntun Cara Modern Menganalisis Tumbuhan, Edisi kedua, diterjemahkan oleh Kosasih Padmawinata dan Iwang Soediro, Penerbit ITB, Bandung.

List, P,H., and Schmidt, P.C. 1989. Phytopharmaceutical Technology, Florida, CRC Press. P53-56.

Lomlin, L., Jirayupong, N., Plubrukan, A. 2003. Heat-Accelerated of Solid-State Andrographolide. Chem.Pharm.Bull J. 51(1): 24-26.

Luque de Castro, M. D. and Garcia-Ayuso, L. E. 1998. Soxhlet extraction of solid materials: an outdated technique with a promising innovative future, Analitica Chimica Acta, 369, 1-10.

Martono, S. 2011. Tehnik Perhitungan Kadar, Modul Kuliah Pascasarjana, Univ. Gadjah Mada, Yogyakarta.

Mulja, M., dan Suharman. 1995. Analisis Instrumental, Airlangga Univ. Press., Surabaya, hal 224.

Mycek, M.J., Harvey, R.A., Champe, P.C., Fisher, B.D. 2001. Farmakologi Ulasan Bergambar Edisi 2, 1995, Cetakan I. Alih bahasa : Prof.dr.H. Azwar Agoes, Widya Medika, 259-263.

Niranjan, A., Tewari, S.K., Lehry, A. 2010. Biological Activities of Kalmegh (A. Paniculata Ness) and Its Active Principles, Indian J. of Nat. Prod. And Res. 1(2): 125135.

Nugroho, A.E., Syamsul, E.S., Andrie, M., Warditiani, K., Lukitaningsih, E., Pramono, S. 2011. The Antidiabetics of Purified Extract of Andrographis paniculata (Burn.f.)Ness and its Active Compound Andrographolide in High Fructose-Fat Fed Rats. Laporan penelitian hibah IMHERE, Fakultas Farmasi UGM, Yogyakarta. 
Nurani, L.H. 2008. Diktat Kuliah Farmakognosi, Fakultas Farmasi Universitas Ahmad Dahlan, Yogyakarta. Hal.31.

Nurani, L.H., Zainab, Kintoko. 2012. Petunjuk Praktikum Analisis Obat Tradisional, Fakultas Farmasi, Universitas Ahmad Dahlan, Yogyakarta p.4-5.

Qiang, Z.Z. 2007. Reaction and Computational Studies of Andrographolide Analogue with Glutathione and Biological Nucleophiles, Desertation, City University of Hongkong, Hongkong.

Reyes, B.A., Bautista, N.D., Tanquilut, N.C., Anunciado, R.V., Leung, A.B., Sanchez, G.C., Magtoto, R.L., Castronuevo, P., Tsukamura, H., Maeda, K.I.. 2006. Antidiabetic potentials of Momordica charantia and Andrographis paniculata and their effects on estrous cyclicity of alloxan-induced diabetic rats. J.Ethnopharmacol. 105(1-2): 196-200.

Saifudin, A., Rahayu, V., dan Teruna, H.Y. 2011. Standardisasi Bahan Obat Alam, Graha Ilmu, Yogyakarta.

Soediro, S. 1973. Pemeriksaan zat pahit dalam daun sambiloto (Andrographis paniculata Nees dari Bandung, Jawa). Acta Pharmaceutica.

Stahl, E. 1985. Analisis Obat dengan Kromatografi dan Mikroskopi, diterjemahkan oleh Kosasih Padmawinata, Penerbit ITB Bandung.

Sudarsono, Puidjoarinto, A., Gunawan, D., Wahyuono, S., Donatus, I.A., Drajad, M., Wibowo, S., Ngatidjan. 2006. Tumbuhan Obat 1. Pusat Penelitian Obat Tradisional, Universitas Gadjah Mada, Yogyakarta. Hal 25-28.

Sudjadi. 1988. Metode Pemisahan, Kanisius, Yogyakarta.

Sule, Q.U., Ahmed, O.A., Samah, Omar, M.N. 2010. Screening for Antibacterial Activity of Andrographis paniculata Used in Malaysian Folkloric Medicine: A Possible
Alternative for the Treatment of Skin Infections. Malay.J.of Med.Sci., Pubmed .

Zang, X.F., and Tan, B.K. 2000. Antihyperglycemic and antioxidant Properties of Andrographis paniculata in Normal and Diabetic Rats. J.Clin.Exp. Pharmacol Physiol. 27 (3): 58-63. 